\title{
Sympathetic Nerves Positively Regulate Eosinophil-Driven Allergic Conjunctivitis via a1-Adrenergic Receptor Signaling
}

Jun Liu, ${ }^{*}$ Shuoya Huang, ${ }^{* \dagger}$ Fanying Li, ${ }^{\ddagger}$ Mingjuan Wu, ${ }^{*}$ Jingxin He, ${ }^{* \dagger}$ Yunxia Xue, ${ }^{*}$ Ting Fu, ${ }^{*}$ Ruoxun Yu, ${ }^{\dagger \dagger}$ Xinwei Chen, ${ }^{*}$ Yuming Wang, and Zhijie Li* ${ }^{*} \uparrow$

From the International Ocular Surface Research Center,* Institute of Ophthalmology and Key Laboratory for Regenerative Medicine, and the Department of Microbiology and Immunology, ${ }^{\ddagger}$ School of Medicine, Jinan University, Guangzhou; the Department of Ophthalmology, ${ }^{\dagger}$ The First Affiliated Hospital of Jinan University, Guangzhou; and the Departments of Science and Technology Administration, ${ }^{\S}$ and the Department of Ophthalmology, ${ }^{\circledR}$ Henan Provincial People's Hospital, Henan University People's Hospital, Zhengzhou University People's Hospital, Zhengzhou, China

Accepted for publication February 20, 2020.

Address correspondence to Zhijie Li, M.D., Ph.D., International Ocular Surface

Research Center, Institute of Ophthalmology, Jinan University Medical School, Guangzhou 510632, China. E-mail: tzhijieli@jnu.edu.cn.

\begin{abstract}
Eosinophils are a major cause of tissue injury in allergic conjunctivitis. The biological nature of eosinophils in the conjunctiva and the mechanisms that control eosinophils' responses in allergic conjunctivitis are currently not completely understood. This study reports that conjunctival eosinophils comprise two populations-Siglec- $F^{\text {int }}$ and Siglec $-F^{\text {hi }}$-in different life stages. Siglec $-F^{\text {int }}$ eosinophils partly expressed CD34 and were in the immature (or steady) state. Siglec- $\mathrm{F}^{\text {hi }}$ eosinophils did not express CD34, sharply increased in number after short ragweed (SRW) pollen challenge, and were in the mature (or activated) state. Moreover, chemical sympathectomy by 6 -hydroxydopamine reduced the recruitment and activation of eosinophils, whereas the activation of the sympathetic nerve system (SNS) with restraint stress accelerated the recruitment and activation of eosinophils in SRW-induced conjunctivitis. It was also found that two eosinophil populations expressed alpha-1a-adrenergic receptors ( $\alpha 1 a-A R s)$; in SRW-induced conjunctivitis, treatment with an $\alpha 1 \mathrm{a}-\mathrm{AR}$ antagonist decreased eosinophil responses, whereas treatment with an $\alpha 1 \mathrm{a}-\mathrm{AR}$ agonist aggravated eosinophil responses. Thus, eosinophil responses in conjunctivitis are regulated by the SNS via $\alpha 1 a-A R$ signaling. SNS inputs or $\alpha 1 a-A R$ function may be potential targets for the treatment of allergic conjunctivitis. (Am J Pathol 2020, 190: 1298-1308; https://doi.org/10.1016/j.ajpath.2020.02.004)
\end{abstract}

Allergies are a major public health problem with a high socioeconomic impact. ${ }^{1,2}$ Approximately half of all allergic patients experience allergies on the ocular surface., Allergic conjunctivitis is a common inflammatory disease of the eyes, which can be classified as either mild transient inflammation (seasonal conjunctivitis) or severe chronic inflammation (vernal keratoconjunctivitis). ${ }^{5,6}$ The responses of allergic conjunctivitis include two phases: the early IgEdependent response after a 15-minute exposure to the allergen, which results in itchiness, eyelid swelling, conjunctival edema, and mucus accumulation, and the late $\mathrm{T}$ helper 2 (Th2)-type inflammatory cytokine-dependent response after 12-24 hours of exposure to the allergen, ${ }^{7-9}$ which involves the recruitment of eosinophils.
The infiltration of eosinophils is a major cause of tissue injury and remodeling in allergic diseases. ${ }^{10}$

Eosinophils are granulocytic leukocytes that contain a bilobed nucleus and are differentiated from CD34 ${ }^{+} \mathrm{IL}-5 \mathrm{R} \alpha^{+}$ eosinophil progenitors (EoPs). ${ }^{11}$ These progenitors derive from hematopoietic stem cells in bone marrow and differentiate into mature eosinophils when they are exposed to

Supported by National Natural Science Foundation of China grants 81470603 (Z.L.), 81770962 (Z.L.), and 81700808 (Y.X.); the Ministry of Science and Technology of the People's Republic of China grant 2018YFC0114500 (Y.W. and Z.L.); and the PhD Start-up Fund of the Natural Science Foundation of Guangdong Province of China grant 2018A030310605 (J.L.).

Disclosures: None declared. 
IL-3, granulocyte-macrophage colony stimulating factor (GM-CSF), and IL-5. ${ }^{12}$ It was traditionally believed that EoPs in bone marrow completely differentiate into mature eosinophils before migrating into peripheral tissues ${ }^{13}$; however, recent research has indicated that some $\mathrm{CD} 34^{+} \mathrm{CCR} 3^{+}$EoPs reside in lung tissues, and these cells rapidly increase and show significant proliferative capacity when stimulated by allergens. ${ }^{14}$ Moreover, eosinophils in lung tissues have been confirmed to belong to a heterogeneous population when exposed to allergens; they were classified into Siglec- $\mathrm{F}^{+} \mathrm{Gr}-1^{\text {hi }}$ and Siglec- $\mathrm{F}^{+} \mathrm{Gr}-1^{-} .{ }^{15}$ Although the roles of eosinophils have been addressed in the ocular allergy model, ${ }^{16-19}$ the subsets of eosinophils in conjunctiva have not been well understood.

Eosinophilia is a hallmark of allergic diseases, such as asthma, rhinitis, and allergic dermatitis. ${ }^{20} \mathrm{~A}$ clear understanding of the mechanisms that control the recruitment of eosinophils in allergic diseases will help us locate potential targets for the therapy of eosinophilia-related allergic diseases. An increasing number of studies have confirmed that the sympathetic nerve system (SNS) plays a crucial role in regulating many immune cells. ${ }^{21-23}$ The SNS was also reported to participate in allergic diseases. ${ }^{24}$ Eosinophils have been described as being in close proximity to the $\mathrm{SNS},{ }^{25}$ and the adrenaline $-\alpha / \beta$-adrenergic receptor (AR) axis controls eosinophil responses. ${ }^{26}$ The expression of ARs in conjunctival eosinophils and the relationship between the SNS and eosinophil responses in allergic conjunctivitis remain unclear.

In this study, we identified and analyzed the heterogeneity of conjunctival eosinophils through immunostaining and flow cytometry. By using flow cell sorting and quantitative PCR (qPCR) analysis, the expression levels of ARs in conjunctival eosinophils were measured. With short ragweed (SRW) pollen-induced allergic conjunctivitis, chemical sympathectomy, restraint stress, and antagonist or agonist treatment, the changes in each eosinophil population and the relationship between the SNS and the eosinophil responses in allergic conjunctivitis were investigated.

\section{Materials and Methods}

\section{Animals}

Wild-type albino laboratory BALB/c specific pathogen-free mice aged 7 to 8 weeks that had no eye diseases were purchased from the Medical Experimental Animal Center (Guangdong, China). All animal procedures were approved by the Jinan University Laboratory Animal Committee on Animal Welfare. All of the animals were treated in conformity with the Association for Research in Vision and Ophthalmology's Statement for the Use of Animals in Ophthalmology and Vision Research and the guidelines of the Animal Experimental Committee at Jinan University. The animals were anesthetized by inhalation of $2 \%$ isoflurane and euthanized with an overdose of carbon dioxide and cervical dislocation.

\section{Induction of Allergic Conjunctivitis}

The procedures were performed as previously described with modification from footpad injection to intraperitoneal injection for allergen sensitization. ${ }^{7,27,28}$ Briefly, BALB/c mice were immunized with $50 \mu \mathrm{g}$ of SRW pollen (Greer Lab, Lenoir, NC) in $5 \mathrm{mg}$ of Imject Alum (Pierce Biotechnology, Rockford, IL) by intraperitoneal injection on day 0 . All of the mouse eyes were topically treated with $0.5 \mathrm{mg}$ SRW in $10 \mu \mathrm{L}$ of phosphate-buffered saline (PBS) by eye drops daily, from days 6 to 12 .

\section{Clinical Scoring of Allergic Conjunctivitis}

Mice were examined clinically for signs of immediate hypersensitivity 20 minutes after each topical SRW challenge and for late-phase reaction 6 hours after each topical SRW challenge, as described previously. ${ }^{29,30}$ Lid swelling, tearing, conjunctival chemosis, and conjunctival redness, were each scored on a scale of 1 to 3 , and the scores were summed. $^{9}$

\section{Immunostaining}

The entire ocular surface, including the cornea and the conjunctiva up to the mucocutaneous junction, was dissected, as described previously. ${ }^{31}$ Briefly, the entire eye was dissected together with the eyelid and fixed in paraformaldehyde for 1 hour. Next, under the dissecting microscope, the tissues were clipped to remove muscle and other accessory tissues so that only the conjunctival tissues remained. The conjunctival tissues were then blocked in $2 \%$ bovine serum albumin for 15 minutes, followed by permeabilization in $0.2 \%$ Triton $\mathrm{X}-100$ for 15 minutes at room temperature. Subsequently, the conjunctival tissues were incubated with phycoerythrin (PE)-conjugated anti-mouse Siglec-F (552126; BD Biosciences, San Jose, CA), Alexa Fluor 488-conjugated anti-mouse CD125 antibody (558533; BD Biosciences), or fluorescein isothiocyanate-conjugated anti-mouse CCR3 antibody (144510; BioLegend, San Diego, CA) at $4^{\circ} \mathrm{C}$ overnight. The stained conjunctival tissues were washed three times with PBS and placed on glass slides to flatten them. A mounting medium containing 1 $\mu \mathrm{mol} / \mathrm{L}$ DAPI (28718-90-3; Sigma-Aldrich, St. Louis, MO) was put on the conjunctival tissues. Images of the conjunctiva were analyzed using a DeltaVision microscopy imaging system (Applied Precision, Issaquah, WA).

\section{Chemical Sympathectomy}

First, 6-hydroxydopamine (6-OHDA) (H2380; SigmaAldrich) was freshly prepared for each experiment and was given to mice by intraperitoneal injection $(200 \mathrm{mg} /$ $\mathrm{kg}){ }^{32,33}$ After 2 weeks, immunostaining of the SNS was performed to confirm to ablation of the SNS after a 10-day 6-OHDA treatment, as previously described. ${ }^{33}$ Once 
ablation of the SNS was successful, the induction of allergic conjunctivitis was performed as described above. After the induction of allergic conjunctivitis, conjunctival tissues were obtained to conduct further analysis (Supplemental Figure S1).

\section{Restraint Stress Model}

The restraint stress model was used to activate the SNS, as described previously. ${ }^{34-36}$ Briefly, mice were confined in ventilated $50-\mathrm{mL}$ conical tubes for a period of 12 hours during their active nocturnal cycle. Restraint started at 6:00 PM (dark onset) and ended at 6:00 AM (light onset). The restraint was initiated 3 days before SRW-induced conjunctivitis and was also performed each day during the period of SRW challenge. Control mice were free to roam in their cages but without food and water during the treatment period. The plasma norepinephrine was then determined with an enzyme-linked immunosorbent assay kit (HEA907Ge; Cloud-Clone Corp, Wuhan, China) to validate the activation of SNS after 3 days of restraint treatment.

\section{RNA-Seq Analysis}

RNA-sequencing (RNA-seq) analysis was performed as described previously by the authors' group. ${ }^{37}$ Briefly, conjunctival tissues were cut into pieces and smashed with a TissueRuptor (Qiagen, Hilden, Germany) in Buffer RZ (RK145; Tiangen, Beijing, China). Total RNA of the conjunctival tissues was obtained using an RNAsimple Total RNA Kit (DP419; Tiangen) and sent to BGI (Guangdong, China) for mRNA sequencing analysis. For the differentially expressed genes, a volcano plot was created using Excel 2010 software (Microsoft, Redmond, WA). These genes, which are used for plotting heat maps, were sorted from the differentially expressed genes with the Kyoto Encyclopedia of Genes and Genomes (KEGG) pathway. Molecular network analysis results for RNA-seq data were visualized with Cytoscape software version 3.7.2 (Free Software Foundation, Boston, MA; https:// cytoscape.org/download.html).

\section{Pharmacologic Agonism and Antagonism}

To observe the roles of $\alpha 1 \mathrm{a}-\mathrm{AR}$ in eosinophil responses, the $\alpha$ la-AR agonist A 61603 hydrobromide $(5 \mu \mathrm{L}, 2.5$ $\mu \mathrm{mol} / \mathrm{L}$; 1052; Tocris Bioscience, Abingdon, UK) and the antagonist tamsulosin (TAM) hydrochloride $(5 \mu \mathrm{L}, 20$ $\mu \mathrm{mol} / \mathrm{L} ; 3050 / 10$; Tocris) were administered by subconjunctival injection.

\section{Flow Cytometric Analysis}

Conjunctival tissues were cut into pieces and digested in 0.4\% collagenase type I (C0130; Sigma-Aldrich) for 30 minutes. After washing with PBS, the digested suspension was passed through a $75-\mu \mathrm{m}$ filter to obtain single cells. These single conjunctival cells were blocked in Flow Cytometry Staining Buffer (00-4222; eBioscience, San Diego, CA), which contains anti-CD16/32 antibody (1:100; 14-0161-85; eBioscience), at room temperature for $10 \mathrm{mi}-$ nutes and were then incubated in a mixture of the following antibodies (1:100) at room temperature for 30 minutes: allophycocyanin-conjugated anti-mouse CD45 antibody (559864; BD Biosciences), PE-conjugated anti-mouse Siglec-F antibody (552126; BD Biosciences), Brilliant Violet 421-conjugated anti-mouse CD64 antibody (139309; BioLegend), and either Alexa Fluor 488-conjugated antimouse CD125 antibody (558533; BD Biosciences) or fluorescein isothiocyanate-conjugated anti-mouse CCR3 antibody (144510; BioLegend), or fluorescein isothiocyanate-conjugated anti-mouse CD34 antibody (553733; BD Biosciences). After washing with PBS, the stained cells were analyzed with a BD FACSCanto.

\section{Transcript Amplification from Conjunctival Eosinophils}

Digested conjunctival cells using collagenase type I were incubated in a 1:100 mixture of the following antibodies at room temperature for 30 minutes: allophycocyaninconjugated anti-mouse CD45 antibody, PE-conjugated anti-mouse Siglec-F antibody, and Brilliant Violet 421-conjugated anti-mouse CD64 antibody. With the flow cell sorter, Siglec- $\mathrm{F}^{\text {hi }} \mathrm{CD} 64^{-}$and Siglec- $\mathrm{F}^{\text {int }}{ }^{-}$D6 $64^{-}$cells were sorted. The transcripts of these cells were amplified using a REPLI-gWTA Single Cell Kit (150063; Qiagen), as previously described. ${ }^{38-40}$

\section{qPCR}

mRNA levels were analyzed by qPCR. Conjunctival tissues were cut into pieces and homogenized with a TissueRuptor (Qiagen) in Buffer RZ (RK145; Tiangen, Beijing). Total RNA of these tissues was extracted using an RNAsimple Total RNA Kit (DP419; Tiangen). cDNA from the conjunctival tissues was obtained from the extracted total RNA with the ReverTra Ace qPCR RT Kit (FSQ-101; Toyobo, Osaka, Japan). The expression level of the target genes of the conjunctival tissues and the amplified transcripts of the conjunctival eosinophils were evaluated using THUNDERBIRD SYBR qPCR Mix (QPS-201; Toyobo). The qPCR primers that were used in this study are listed in Table 1.

\section{Statistical Analysis}

The results are presented as means \pm SD. For comparisons between groups, one-way analysis of variance was performed, followed by Tukey's HSD test. Statistical significance was set at $P<0.05$. 


\section{Results}

\section{Conjunctiva Contain Distinct Eosinophil Populations}

The cell surface markers Siglec-F, CCR3, and IL-5Ra (CD125) are generally used to identify eosinophils in mice. ${ }^{15,41}$ Immunostaining analysis revealed that many Siglec- $\mathrm{F}^{+}$cells exist in mouse conjunctiva, and these cells were $\mathrm{CCR}^{+}$and $\mathrm{CD} 125^{+}$(Figure $1 \mathrm{~A}$ ). In the lung tissues, some Siglec- $\mathrm{F}^{+}$cells were identified as macrophages. ${ }^{41}$ Therefore, the authors used CD64, which is a specific marker of macrophages,${ }^{42}$ to exclude the macrophages in the $\mathrm{CD}_{4} 5^{+}$Siglec- $\mathrm{F}^{+}$conjunctival cells by flow cytometry. However, all $\mathrm{CD} 45^{+}$Siglec- $\mathrm{F}^{+}$cells in the conjunctiva were $\mathrm{CD}^{-} 4^{-}$. Some researchers have revealed that the expression levels of Siglec-F can be used to discriminate the maturation or activation of eosinophils. ${ }^{43-45}$ In the present study, Siglec- $\mathrm{F}^{+}$conjunctival cells were classified into two populations: the Siglec- $\mathrm{F}^{\text {int }}$ and Siglec-F $\mathrm{F}^{\text {hi }}$ cells. Further analysis indicated that Siglec- $F^{\text {int }}$ and Siglec- $F^{\text {hi }}$ conjunctival eosinophils have distinct phenotypes; Siglec-F F $^{\text {int }}$ eosinophils were $\mathrm{CD} 45^{\text {int }} \mathrm{CD} 125^{\text {lo }} \mathrm{CD} 34^{+/-}\left(10.9 \% \mathrm{CD}^{+} 4^{+}\right)$, and Siglec- $F^{\text {hi }}$ eosinophils were $\mathrm{CD} 45^{\text {hi }} \mathrm{CD} 125^{\text {int }}$ CD $34^{-}$ (Figure 1B).

\section{Allergic Conjunctivitis Is Associated with High Numbers of Siglec- $\mathrm{F}^{\text {hi }}$ Eosinophils}

To investigate changes in the two eosinophil populations in allergic conjunctivitis and their contribution to it, SRW pollen was used to establish an allergic conjunctivitis model. After stimulation with SRW, BALB/c mice showed typical signs of allergic conjunctivitis, including eyelid swelling, tearing, conjunctival chemosis, conjunctival redness (Figure 2A), frequent scratching of the eyelids, and high clinical scores (Figure 2B). This was followed by a Th2 inflammatory response in the conjunctival tissues. The gene expression levels of Il4, Il5, and Il13 in the conjunctiva were markedly increased after six repeated SRW challenges (Figure 2C). In this study's immunostaining and flow cytometry analysis, an increase of eosinophils was also clearly observed within the conjunctival tissues in SRWtreated mice. The percentage of Siglec- $\mathrm{F}^{+}$cells within the conjunctival cells showed a approximately sevenfold increase, whereas within the $\mathrm{CD} 45^{+}$cells, a approximately fourfold increase was seen in SRW-treated mice compared with saline-treated control mice. In control mice, the proportion of Siglec- $\mathrm{F}^{\text {hi }}$ eosinophils within the conjunctival cells was almost equivalent to that of the Siglec- $\mathrm{F}^{\text {int }}$ eosinophils, and the eosinophil ratio (Siglec- $\mathrm{F}^{\text {hi }} /$ Siglec-F $\left.{ }^{\text {int }}\right)$ was about one. After the induction of conjunctivitis with repeated SRW challenges, the Siglec- $\mathrm{F}^{\text {hi }}$ eosinophils increased, and the eosinophil ratio (Siglec- $\mathrm{F}^{\mathrm{hi}} /$ Siglec- $\mathrm{F}^{\mathrm{int}}$ ) increased to approximately 3.5 (Figure 2, D-F).
Table 1 PCR Primers Used in This Study

\begin{tabular}{|c|c|c|}
\hline \multirow{3}{*}{$\begin{array}{l}\text { Gene name } \\
\text { Il4 }\end{array}$} & \multicolumn{2}{|c|}{ Primer pair } \\
\hline & Forward & 5'-AGCTAGTTGTCATCCTGCTC-3' \\
\hline & Reverse & 5'-TGTGACCTCGTTCAAAATGC-3' \\
\hline \multirow[t]{2}{*}{ Il5 } & Forward & 5'-GGGGTACTGTGGAAATGCTA-3' \\
\hline & Reverse & 5'-TTGTGGGGTTTTTGCATCTG-3' \\
\hline \multirow[t]{2}{*}{ Il13 } & Forward & $5^{\prime}-\mathrm{GCAACATCACACAAGACCAG-3^{ \prime }}$ \\
\hline & Reverse & 5'-AGGCCATGCAATATCCTCTG-3' \\
\hline \multirow[t]{2}{*}{ Adra1a } & Forward & 5'-GTGGAGTTATTGGATCGCTG-3' \\
\hline & Reverse & 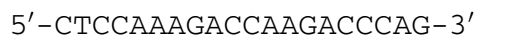 \\
\hline \multirow[t]{2}{*}{ Adra1b } & Forward & $5^{\prime}-$ AGGGAAAGAAGAGTATTTGGG-3' \\
\hline & Reverse & 5'-TTGTGCTTTCTGATCCAAAC-3' \\
\hline \multirow[t]{2}{*}{ Adra1d } & Forward & 5'-TTTTACTCСТTACTGCCACC-3' \\
\hline & Reverse & 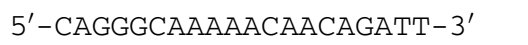 \\
\hline \multirow[t]{2}{*}{ Adra2a } & Forward & 5'-CTGCTTTGACATTTCCTGAC-3' \\
\hline & Reverse & 5'-CTTGGTCCATCGCTGTAATA-3' \\
\hline \multirow[t]{2}{*}{ Adra2b } & Forward & $5^{\prime}-$ TCACTAAGGTCCTGATCACT-3' \\
\hline & Reverse & $5^{\prime}-\mathrm{AAACACACAGGAAAGGGATT-3^{ \prime }}$ \\
\hline \multirow[t]{2}{*}{ Adra2c } & Forward & 5'-GTTCCCCTTCTTCTTCAGCT-3' \\
\hline & Reverse & 5'-ССТTСТССТССТTCGAAAG-3' \\
\hline \multirow[t]{2}{*}{ Adrb1 } & Forward & 5'-TTACTCAAGACCGAAAGCAG-3' \\
\hline & Reverse & 5'-CCATACTAAGCCACACTCTC-3' \\
\hline \multirow[t]{2}{*}{ Adrb2 } & Forward & 5'-СTCСТTTTTGCСТАTCCAGA-3' \\
\hline & Reverse & 5'-GCACGTAGAAAGACACAATC-3' \\
\hline \multirow[t]{2}{*}{ Adrb3 } & Forward & 5'-TTCCGTCGTCTTCTGTGTAGC-3' \\
\hline & Reverse & $5^{\prime}$-АCCTTCATAGCCATCAAACCTGT-3' \\
\hline \multirow[t]{2}{*}{ Gapdh } & Forward & $5^{\prime}-\mathrm{CAAGGACACTGAGCAAGAG-3^{ \prime }}$ \\
\hline & Reverse & 5'-TGCAGCGAACTTTATTGATG-3' \\
\hline
\end{tabular}

Sympathetic Nerves Regulate Inflammation and Eosinophil Responses in Allergic Conjunctivitis

A previous study showed the SNS was associated with allergy and modified the immune system in favor of Th2 action. ${ }^{24}$ However, the specific roles of the SNS in allergic conjunctivitis are unclear. To investigate whether the SNS influences inflammation and eosinophil activation in allergic conjunctivitis, a chemical sympathectomy (adrenergic denervation) was performed with 6-OHDA, and the changes in the clinical scores, conjunctival gene transcription, and eosinophil responses after SRW challenge were observed. The clinical scores of 6-OHDA-treated mice were significantly lower than those of saline-treated control mice 20 minutes and 6 hours after SRW challenge at challenge day 6 and 7 (Figure 3A). RNA-seq results revealed that the conjunctival gene transcription had changed, with 259 genes down-regulated and 46 genes up-regulated in 6OHDA-treated mice after SRW challenge, compared with control mice after SRW challenge (Figure 3B). The expression of genes that are involved in the immune system process and the NF-kappa B and chemokine signaling pathways had all decreased in the conjunctival tissues of 6OHDA-treated mice (Figure 3, C, D, and E). By Cytoscape network analysis, those genes involved in the regulation of Th2 cell differentiation, the type 2 response, and eosinophil chemotaxis were all down-regulated in conjunctival tissues 
A

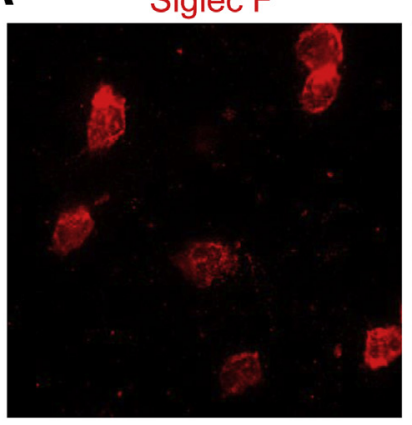

Siglec F

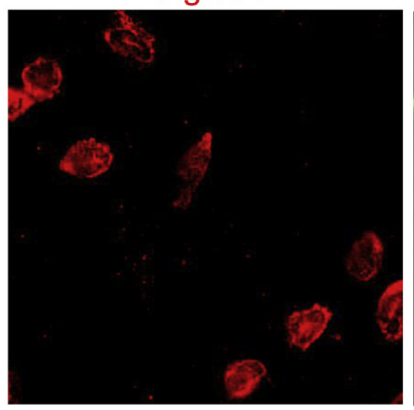

B

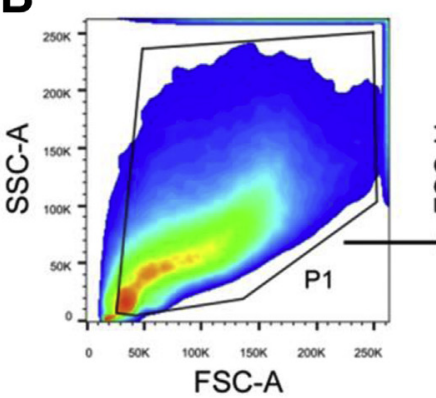

CCR3

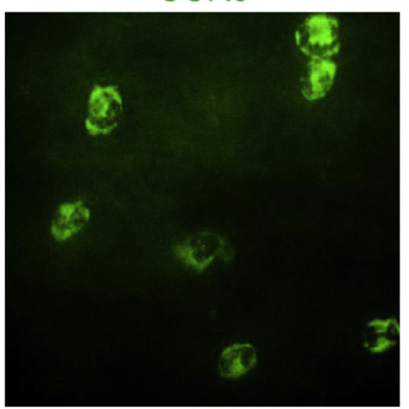

CD125
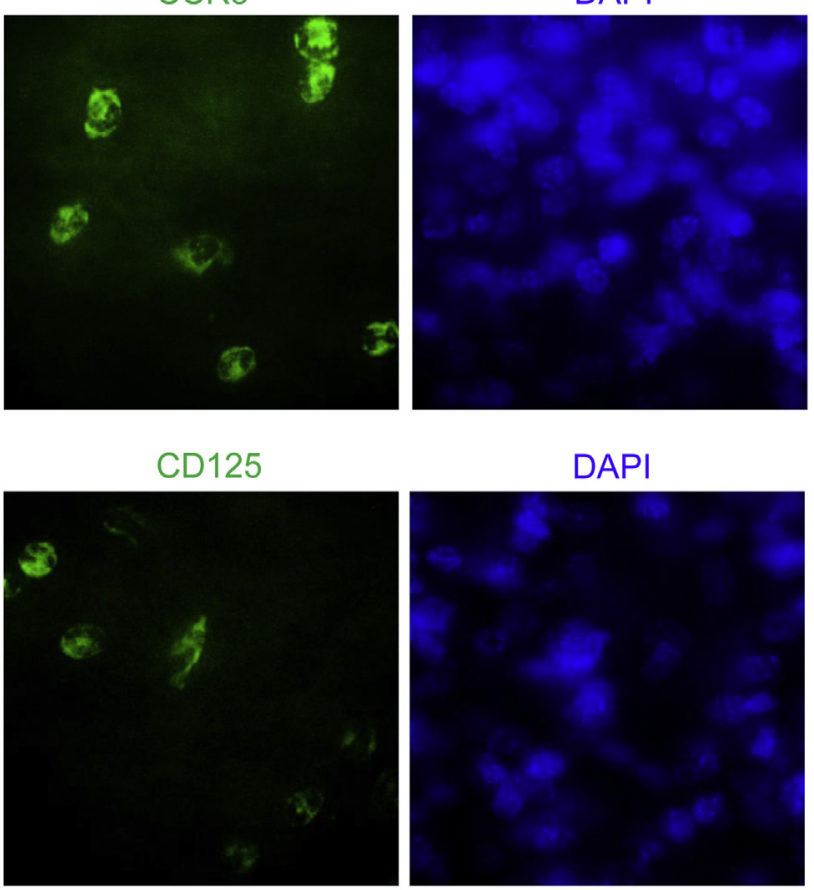

DAPI
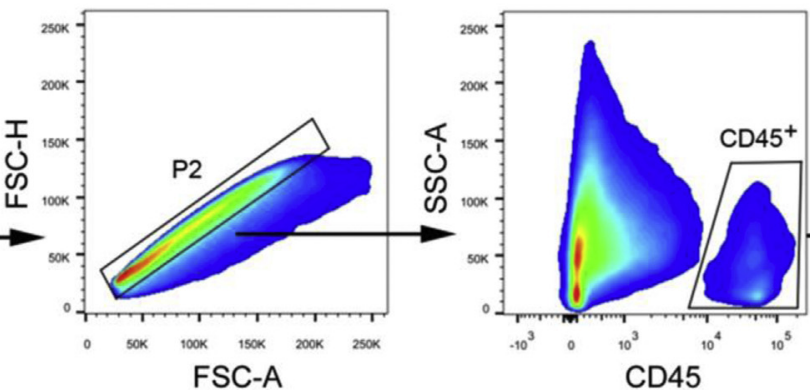

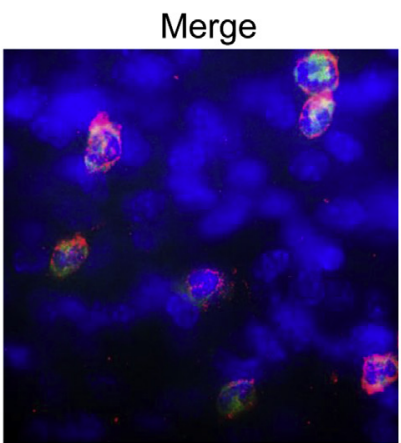

Merge
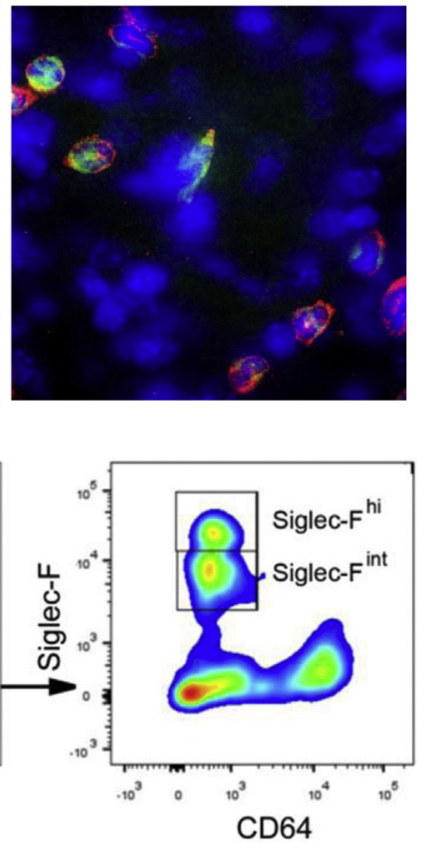

$\mathrm{CD}^{2} 5^{+}$Siglec-F ${ }^{+} \mathrm{CD}^{-} 4^{-}$
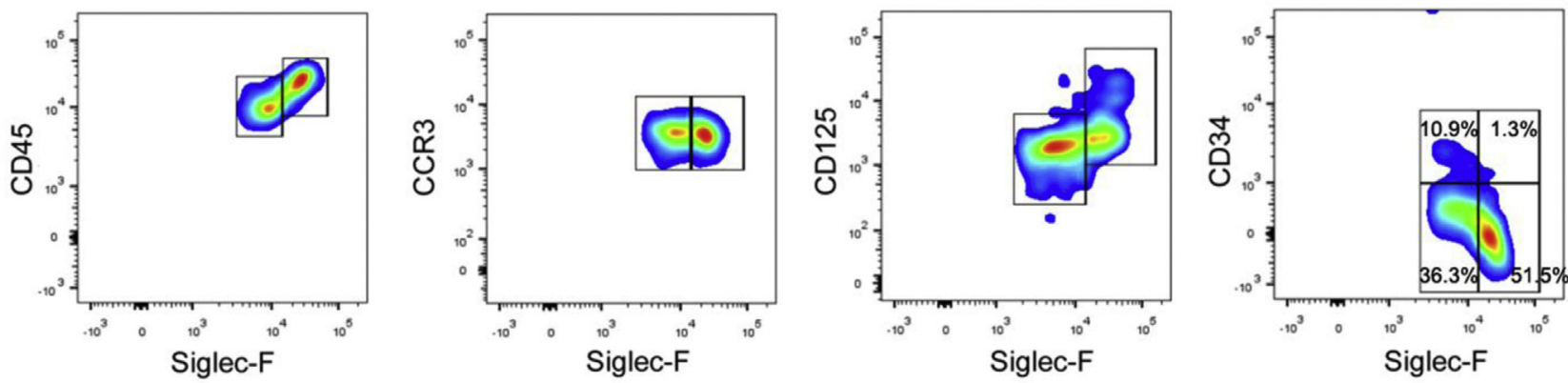

Figure 1 Identification of eosinophils in conjunctiva. A: Immunostaining of the intact conjunctiva with anti-mouse Siglec-F, anti-mouse CCR3, and antimouse CD125 antibodies. B: Analysis of the expression of CD45, CCR3, CD125, and CD34 molecules in each eosinophil population. Top row: P1 represents the population of the intact cells after exclusion of debris; P2, single cells; P3, CD45 positive cell population; P4, cell population that highly expressed Siglec- $F$ antigen; P5, cell population that intermediately expressed Siglec- $F$ antigen. Bottom row: Expression of CD45, CCR3, CD125, and CD34 antigens in Siglec- $F$ (hi) eosinophils and Siglec-F (int) from P4 and P5 cell population are shown, respectively. Original magnification, $\times 400($ A). FSC-A, forward scatter-area; FSC-H, forward scatter-height; SSC-A, side scatter-area.

of 6-OHDA - treated mice after SRW challenge (Figure 3, F and G). The flow cytometry results showed that the proportion of eosinophils in conjunctival cells and $\mathrm{CD}_{4} 5^{+}$ leukocytes had both decreased, and the eosinophil ratio
(Siglec-F ${ }^{\text {hi }} /$ Siglec-F ${ }^{\text {int }}$ ) had decreased from approximately 2.3 to approximately 0.8 (Figure $3 \mathrm{H}$ ). These RNA-seq and flow cytometry results indicate that SNS is important for Th2 inflammatory and eosinophil responses in the allergic 
A

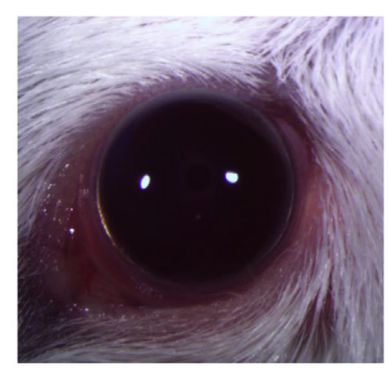

C

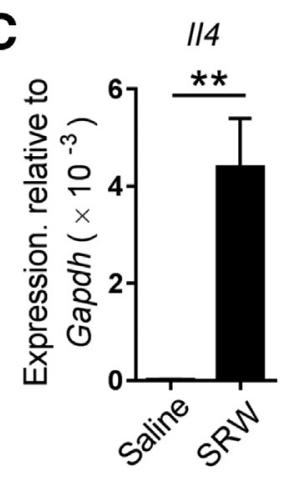

$\mathbf{E}$

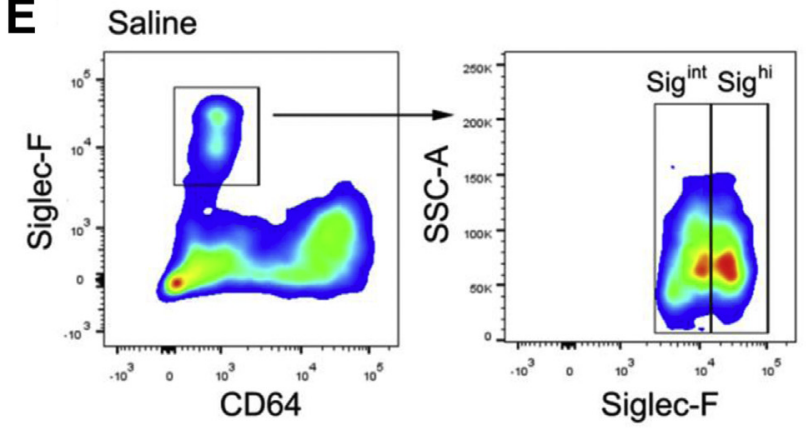

B

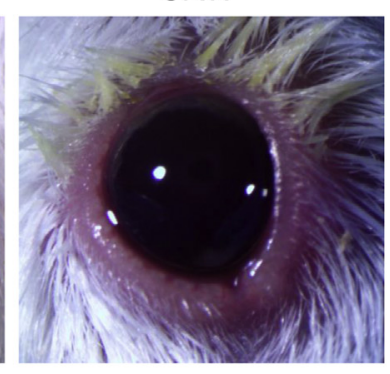

$1 / 5$

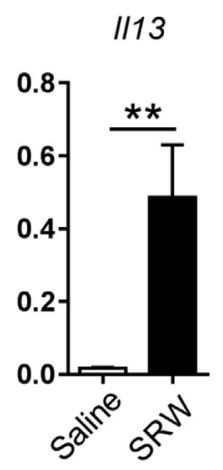

$20 \min$

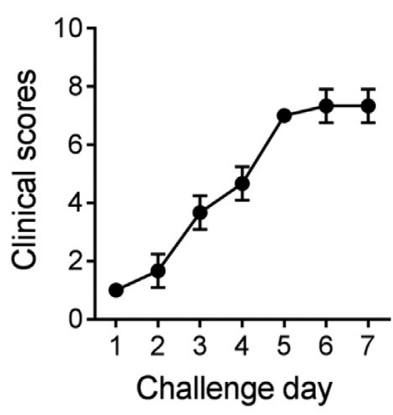

D

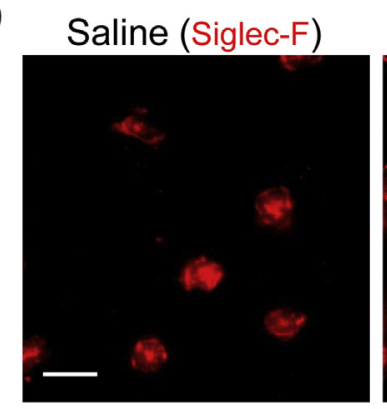

$6 \mathrm{~h}$

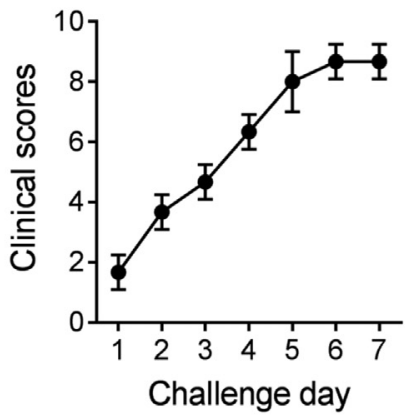

SRW (Siglec-F)

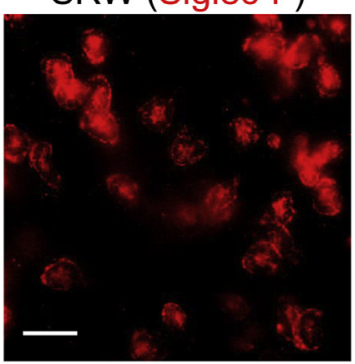

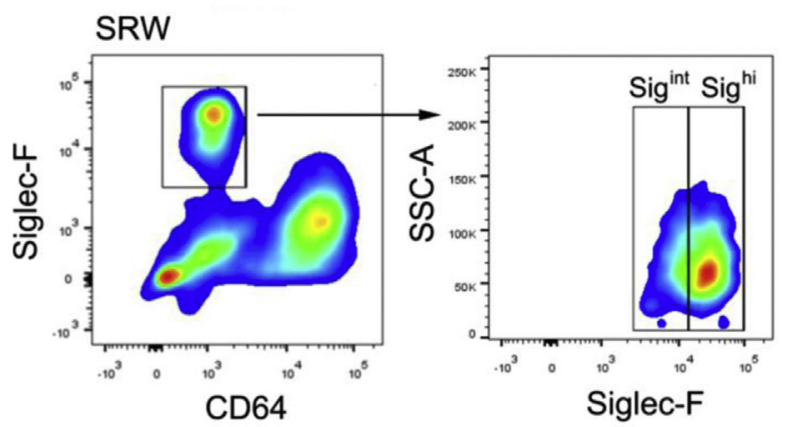

$\mathbf{F}$
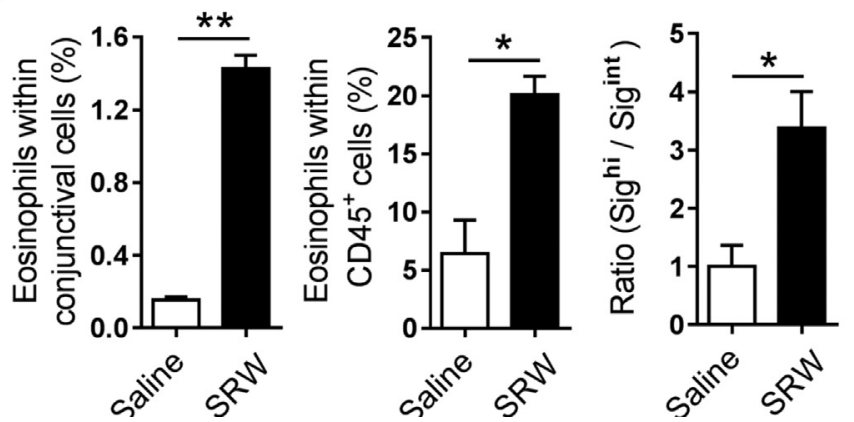

Figure 2 The responses of eosinophils in SRW-induced allergic conjunctivitis. A: Changes in the appearance of the ocular surface at 6 hours after the last SRW challenge. B: Investigation of clinical scores 20 minutes and 6 hours after each SRW challenge. C: Alteration in the gene expression of Th2-type cytokines Il4, Il5, and Il13 in conjunctival tissues at 12 hours after the last SRW challenge. D: Immunostaining of conjunctival tissues from saline-treated control mice and SRWtreated mice at 12 hours after the last SRW challenge with PE-conjugated anti-mouse Siglec-F antibody. $\mathbf{E}$ and $\mathbf{F}$ : Analysis of the changes in the eosinophil number at 12 hours after the last SRW challenge. Data are expressed as means \pm SD. $n=6$ mice at each time point (B); $n=3$ independent experiments (C, E, and F); $n=3$ mice per experiment (C); $n=5$ mice per experiment (E and $\mathbf{F}) .{ }^{*} P<0.05,{ }^{*} P<0.01$. Original magnification, $\times 40$ (D). PE, phycoerythrin; SRW, short ragweed; SSC-A, side scatter-area. 

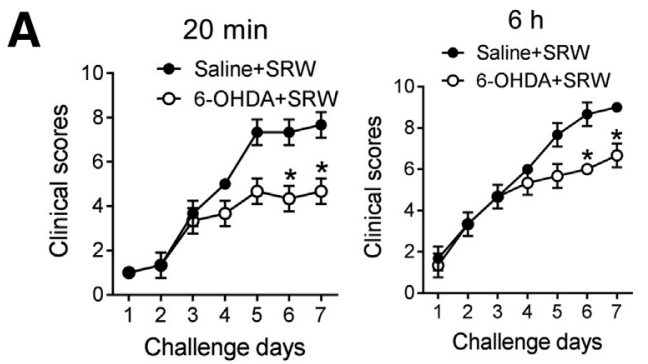

C

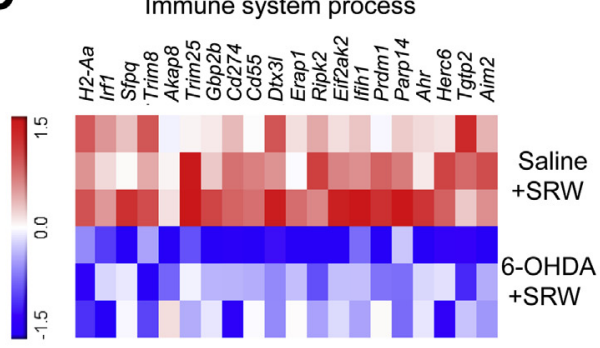

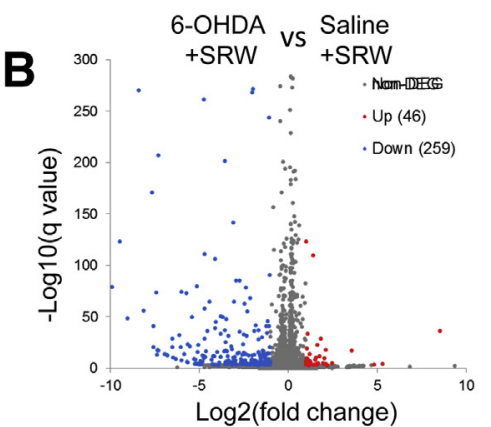

D NF-kappa B signaling pathway

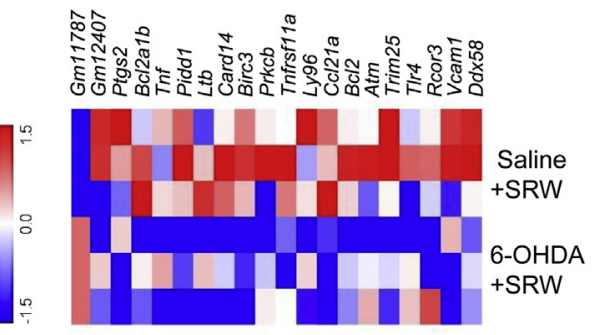

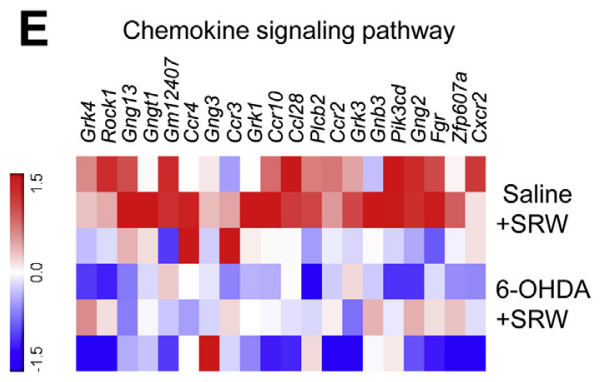

$\mathbf{F}$
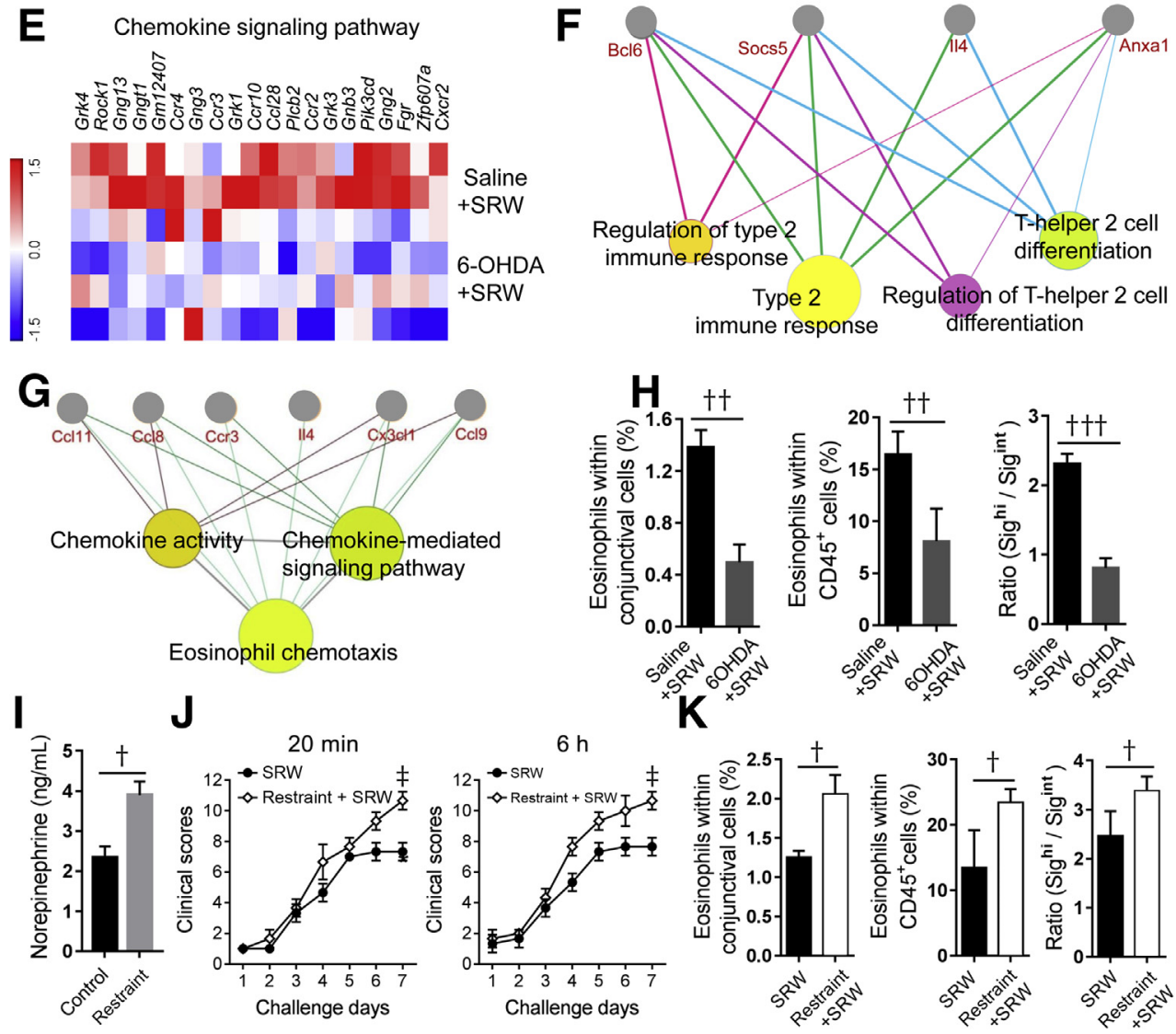

Figure 3 The effects of SNS in conjunctival gene transcription and eosinophil responses in conjunctivitis. A: Clinical scores in 6-OHDA-treated and salinetreated control mice 20 minutes and 6 hours after SRW challenges. B: Volcano plot of differentially expressed genes (DEGs) in allergic conjunctival tissues after 6-OHDA treatment. The numbers in parentheses indicate the number of genes that have been up-regulated (Up) and down-regulated (Down), respectively. C-E: Heat maps of the top 20 DEGs that are involved in immune system processes (C), the nuclear factor (NF)-kappa B signaling pathway (D), and the chemokine signaling pathway (E). F and G: Cytoscape network analysis of transcripts involved in Thelper type 2 (Th2) cell differentiation, the type 2 response, and eosinophil chemotaxis (down-regulated genes are shown in gray). H: Changes in eosinophils in the allergic conjunctiva after 6-OHDA treatment. I: Changes in norepinephrine plasma level after restraint stress treatment. J: Investigation of clinical scores in restraint stress-treated and control mice after SRW challenge. K: The changes in eosinophils in the conjunctiva after restraint stress treatment. B-H and K: All conjunctival tissues in SRW-treated mice were collected at 12 hours after the last SRW challenge. Data are expressed as means \pm SD. $n=6$ mice at each time point $(\mathbf{A}$ and $\mathbf{J}) ; n=3$ independent experiments $(\mathbf{H}$ and $\mathbf{K}) ; n=5$ mice per experiment $(\mathbf{H}$ and $\mathbf{K}) ; n=6$ mice $(\mathbf{I}) .{ }^{*} P<0.05$ versus saline $+\mathrm{SRW} ;{ }^{\dagger} P<0.05,{ }^{\dagger \dagger} P<0.01$, and ${ }^{\dagger \dagger \dagger} P<0.001 ;{ }^{\ddagger} P<0.05$ versus SRW. 6-OHDA, 6-hydroxydopamine; SNS, sympathetic nerve system; SRW, short ragweed. 


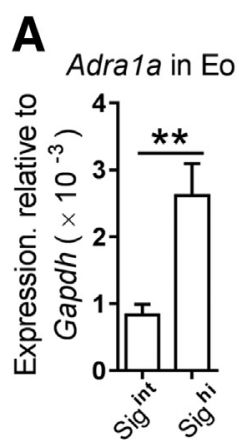

D

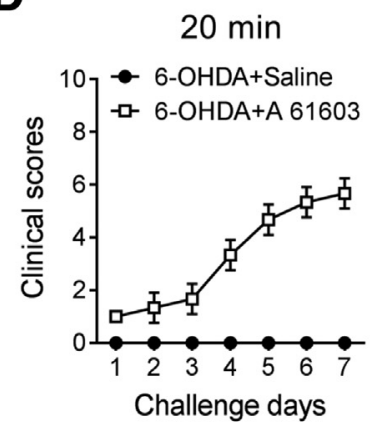

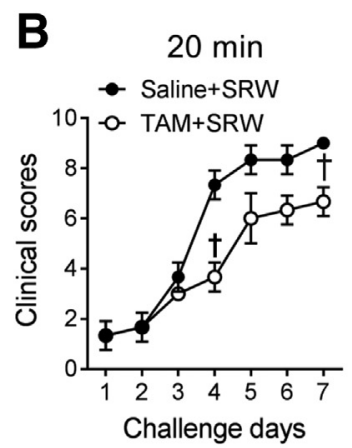

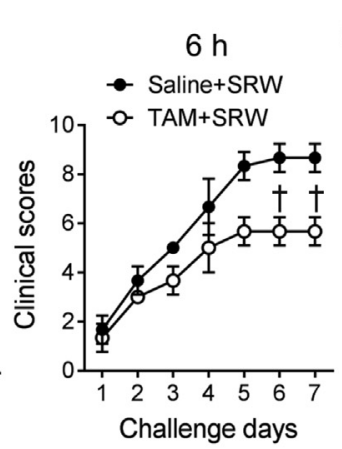

E
C

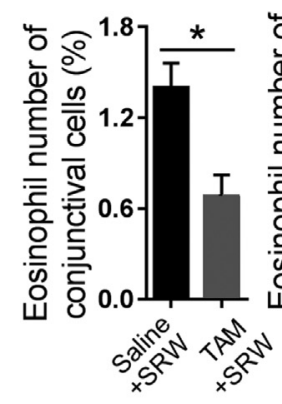

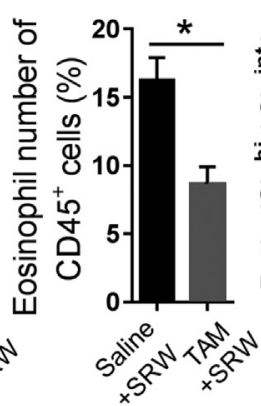

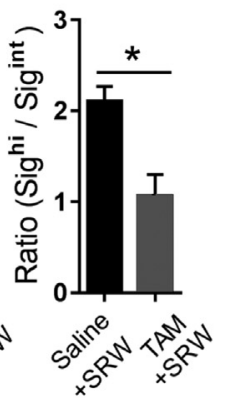

$6 \mathrm{~h}$

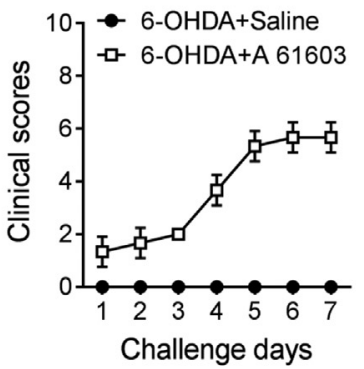

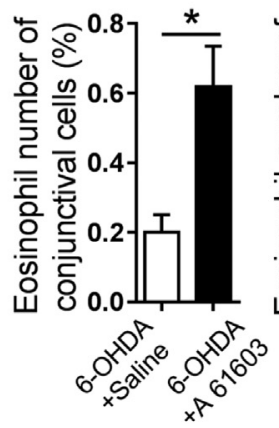

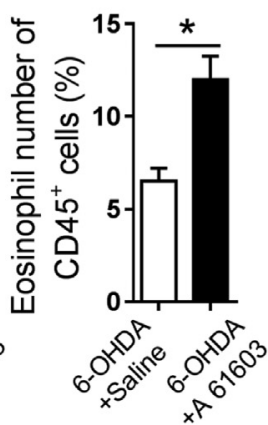

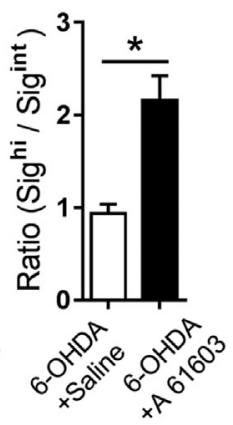

Figure 4 Changes in clinical scores and eosinophil responses after treatment with $\alpha 1 a-A R$ antagonists and agonists. A: Investigation of the expression of Adra1a gene in conjunctival eosinophils (Eo) with quantitative PCR. B: Investigation of clinical scores in TAM-treated and control (saline-treated) mice after SRW challenges 20 minutes and 6 hours at each challenge day. C: Changes of eosinophils in the conjunctiva after TAM treatment. D: Investigation of clinical scores in 6-OHDA treated mice 20 minutes and 6 hours after each challenge in A 61603 hydrobromide-treated or saline-treated mice $(n=6$ mice at each time point). E: Changes in eosinophils in conjunctiva after A 61603 hydrobromide treatment. Data are expressed as means \pm SD. $n=3$ independent experiments $(\mathbf{A}, \mathbf{C}$, and $\mathbf{E}) ; n=3$ mice per experiment $(\mathbf{A}$ and $\mathbf{K}) ; n=6$ mice at each time point $(\mathbf{B}) ; n=5$ mice per experiment $(\mathbf{C}$ and $\mathbf{E}) .{ }^{*} P<0.05,{ }^{* *} P<0.01$; ${ }^{\dagger} P<0.05$ versus saline+SRW. $6-0$ HDA, 6 -hydroxydopamine; AR, adrenergic receptor; SRW, short ragweed; TAM, tamsulosin hydrochloride.

conjunctivitis. Moreover, when using restraint stress to treat mice for 3 days, the norepinephrine plasma levels significantly increased (Figure 3I), indicated that sympathetic nerves were activated. The clinical scores of restraint stress-treated mice increased and were significantly higher than those of control mice after SRW challenge 20 minutes and 6 hours on day 7 (Figure 3J). In addition, restraint stress can accelerate eosinophil responses; the proportion of eosinophils in the conjunctival cells and $\mathrm{CD} 45^{+}$leukocytes, and the eosinophil ratio (Siglec-F ${ }^{\text {hi }} /$ Siglec- $F^{\text {int }}$ ) of the restraint stress-treated group were both higher than those of the control group after SRW challenge (Figure 3K). These results reveal that the SNS controls both the inflammatory and eosinophil responses in conjunctivitis.

\section{Sympathetic Nerves Regulate Eosinophil Responses in Conjunctivitis through the Alpha-1a Adrenergic Receptors}

The activation of SNS usually regulates immune cells through the AR signaling pathway. The ARs have both $\alpha$ and $\beta$ subtypes. By qPCR analysis, eosinophils were confirmed to predominantly express the $\alpha 1 \mathrm{a}-\mathrm{AR}$ gene Adrala (Figure 4A), but the expression level of other adrenergic receptor subtypes such as alpha-adrenergic receptors (Adralb, Adrald, Adra2a, Adra2b and Adra2c) and beta-adrenergic receptors (Adrb1, Adrb2, and Adrb3) were undetectable. This suggests that the SNS may mainly regulate eosinophils through $\alpha 1 \mathrm{a}-\mathrm{ARs}$. To verify this hypothesis, the authors used the $\alpha 1 \mathrm{a}-\mathrm{AR}$ antagonist TAM to block the function of this receptor. The results revealed that the clinical scores were significantly decreased (Figure 4B), and the eosinophil response was attenuated; the percentage of eosinophils within conjunctival cells and $\mathrm{CD}^{4} 5^{+}$leukocytes, and the eosinophil ratio (Siglec- $\mathrm{F}^{\text {hi }} /$ Siglec- $\mathrm{F}^{\text {int }}$ ) in TAM-treated mice were all lower than those in control mice after SRW challenge (Figure 4C). Finally, after treatment with the $\alpha 1 \mathrm{a}-\mathrm{AR}$ agonist A 61603 hydrobromide, the clinical scores and the conjunctival eosinophil responses had both significantly increased in 6-OHDA-treated mice (Figure 4, D and E).

\section{Discussion}

This study shows that conjunctival eosinophils can be classified into two populations with distinct phenotypes: Siglec- $F^{\text {int }}$ and Siglec- $\mathrm{F}^{\mathrm{hi}}$. SRW-induced allergic conjunctivitis was mainly associated with an increase in Siglec- $\mathrm{F}^{\text {hi }}$ eosinophils. Moreover, the authors confirmed that infiltration of these 
eosinophils in SRW-induced allergic conjunctivitis was regulated by the SNS through $\alpha 1 \mathrm{a}-\mathrm{AR}$ signaling.

Eosinophils are granulocytic leukocytes that arise from bone marrow granulocyte-macrophage progenitors through an intermediate-EoPs. These cells are rare in the blood, but they are more abundant in the peripheral tissues. ${ }^{46}$ Until recently, eosinophils were believed to reach maturation in bone marrow before being released into the blood as end-stage granulocytes. However, a recent study reported that CD $34^{+}$ EoPs reside in peripheral tissues and show local proliferative capacity when stimulated by allergens. ${ }^{14}$ Here, the Siglec-F ${ }^{\text {int }}$ and Siglec- $\mathrm{F}^{\mathrm{hi}}$ eosinophil populations were found to be present in the normal conjunctiva. They differ in the expression of some surface antigens, in particular CD34, which is the hematopoietic progenitor marker. Siglec- $F^{\text {int }}$ eosinophils had approximately $10 \% \mathrm{CD}^{+} 4^{+}$cells, whereas Siglec-F ${ }^{\text {hi }}$ eosinophils had none. This suggests that Siglec- $F^{\text {int }}$ eosinophils in conjunctiva may be in the immature stage. Previous studies identified Siglec- $\mathrm{F}^{\text {int }}$ cells as immature (or resting) eosinophils that settled in the lymphoid organs and uninflamed tissues, whereas Siglec- $\mathrm{F}^{\mathrm{hi}}$ cells were distinguished as mature (or activated) eosinophils, which are usually located in the extralymphoid tissues and inflamed tissues. ${ }^{44,45}$ In this study, the number of Siglec-F $F^{\text {int }}$ eosinophils was similar to the number of Siglec- $\mathrm{F}^{\text {hi }}$ eosinophils in the conjunctiva in a steady state. After repeated SRW challenges, the percentage of Siglec-F ${ }^{\text {hi }}$ eosinophils increased, and the eosinophil ratio $\left(\right.$ Siglec-F ${ }^{\text {hi }} /$ Siglec-F ${ }^{\text {int}}$ ) increased from approximately 1 to approximately 3.5 . Thus, the Siglec- $\mathrm{F}^{\mathrm{hi}}$ conjunctival eosinophils can be considered mature or activated eosinophils, which are usually located in inflamed tissues. In addition, the high number of Siglec- $\mathrm{F}^{\text {hi }}$ eosinophils may be considered as a piece of evidence that the tissues were in an inflamed condition.

Traditionally, eosinophils within bone marrow and blood are attracted to inflammatory sites by the Th2 cytokines IL4, IL-5, and IL-13 after exposure to allergens. ${ }^{47}$ Apart from the traditional signaling pathway, which controls the activation and recruitment of eosinophils to allergic tissues, whether there are other signaling pathways that regulate the responses of eosinophils in conjunctivitis is unclear. Recently, many studies have reported that the SNS controls the responses of immune cells. ${ }^{21-23}$ One novel finding focused on the group 2 innate lymphoid cells (ILC2s). These cells were confirmed to be adjacent to the SNS and to express $\beta 2$-ARs. The $\beta 2$-AR signaling pathway negatively regulates ILC2 responses, and deficiency in $\beta 2$-ARs increases ILC2 responses and type 2 inflammation in the lung and intestinal tissues. ${ }^{48}$ In the current study, eosinophils were confirmed to express $\alpha 1 \mathrm{a}$-ARs. This suggests that eosinophils may also exert their functions through the adrenergic signaling pathway. As expected, the activation and migration of eosinophils were inhibited by chemical sympathectomy with 6-OHDA treatment and were augmented by the activation of the SNS with restraint stress treatment in SRW-treated mice. Furthermore, treatment with an $\alpha 1 \mathrm{a}-\mathrm{AR}$ antagonist inhibited and treatment with an
ala-AR agonist promoted eosinophil responses in SRWinduced conjunctivitis. These results indicate that the conjunctival SNS promotes eosinophil responses through $\alpha 1 \mathrm{a}-\mathrm{ARs}$ and that this signaling pathway is different from the $\beta 2$-AR signaling pathway in the intestinal and lung tissues, which negatively regulate ILC2 responses and type 2 inflammation. The results also revealed that the SNS may have distinct effects on the target cells via different AR signaling.

Although this study highlights the important role of the activation of $\alpha 1 \mathrm{a}-\mathrm{AR}$ in murine allergic conjunctivitis, one should consider the complexity of the mechanism underlying allergic conjunctivitis. Many immune cells participate in allergic conjunctivitis. ${ }^{49}$ These cells also express different AR subtypes, including $\alpha 1$ (A, B, and C), $\alpha 2$ (A, B, and D), and $\beta$ (1 to 3)-type ARs, and these may also be modulated by the SNS. ${ }^{50,51}$ For instance, mast cells, ${ }^{52}$ macrophages, ${ }^{53}$ B cells, ${ }^{49,54}$ and neutrophils ${ }^{53,54}$ participate in allergic conjunctivitis and express $\beta$ subtype ARs. Interestingly, infiltrated $\gamma \delta$ T cells in the cornea after corneal abrasion also express $\alpha 1$ a-AR receptors. ${ }^{55}$ Another study confirmed that $\gamma \delta \mathrm{T}$ cells are involved in the occurrence and development of allergic conjunctivitis by regulating Th2 cytokine expression. ${ }^{56}$ Thus, both the mechanism and the role of other immune cells that are mediated by the SNS in allergic conjunctivitis also require further investigation.

Collectively, this study indicates that there are two populations of eosinophils in the conjunctiva: Siglec- $F^{\text {int }}$ and Siglec- $\mathrm{F}^{\text {hi }}$. The two populations represent the different life stages of eosinophils: the immature (or resting) stage and the mature (or activated) stage. The recruitment and activation of eosinophils in conjunctivitis are regulated by the SNS via $\alpha 1 \mathrm{a}-A R s$. These findings improve our understanding of the specific roles of the SNS in the regulation of eosinophil responses, and they provide new potential therapeutic targets for allergic conjunctivitis.

\section{Acknowledgment}

We thank Xinqiang Lai (Core Laboratory for Analysis and Test, Jinan University) for instructions on flow cytometry analysis.

\section{Author Contributions}

Z.L. and J.L. conceived and designed the study; S.H. analyzed immunostaining and performed qPCR; F.L., M.W., J.H., R.Y., and X.C. helped with treatment of the animals, including conjunctivitis induced and drug treatment; J.L. performed flow cytometry analysis; Y.X., T.F., and Y.W. conducted the statistical analysis; J.L. drafted the first version of the paper; Z.L. critically reviewed and revised the paper for intellectual content; all authors critiqued the manuscript and approved its submission. 


\section{Supplemental Data}

Supplemental material for this article can be found at http://doi.org/10.1016/j.ajpath.2020.02.004.

\section{References}

1. Pawankar R: Allergic diseases and asthma: a global public health concern and a call to action. World Allergy Organ J 2014, 7:12

2. Simon D: Recent advances in clinical allergy and immunology. Int Arch Allergy Immunol 2018, 177:324-333

3. Bielory L: Allergic and immunologic disorders of the eye. Part II: ocular allergy. J Allergy Clin Immunol 2000, 106:1019-1032

4. Stahl JL, Barney NP: Ocular allergic disease. Curr Opin Allergy Clin Immunol 2004, 4:455-459

5. Calonge M: Classification of ocular atopic/allergic disorders and conditions: an unsolved problem. Acta Ophthalmol Scand Suppl 1999, 228:10-13

6. Niederkorn JY: Immune regulatory mechanisms in allergic conjunctivitis: insights from mouse models. Curr Opin Allergy Clin Immunol 2008, 8:472-476

7. Stern ME, Siemasko K, Gao J, Duong A, Beauregard C, Calder V, Niederkorn JY: Role of interferon-gamma in a mouse model of allergic conjunctivitis. Invest Ophthalmol Vis Sci 2005, 46:3239-3246

8. Carreras I, Carreras B, McGrath L, Rice A, Easty DL: Activated T cells in an animal model of allergic conjunctivitis. Br J Ophthalmol 1993, 77:509-514

9. Magone MT, Chan CC, Rizzo LV, Kozhich AT, Whitcup SM: A novel murine model of allergic conjunctivitis. Clin Immunol Immunopathol 1998, 87:75-84

10. Miyazaki D, Tominaga T, Yakura K, Kuo C-H, Komatsu N, Inoue Y, Ono SJ: Conjunctival mast cell as a mediator of eosinophilic response in ocular allergy. Mol Vis 2008, 14:1525-1532

11. Nutman TB, Cohen SG, Ottesen EA: The eosinophil, eosinophilia, and eosinophil-related disorders. II. Eosinophil infiltration and function. Allergy Proc 1988, 9:641-647

12. Mori Y, Iwasaki H, Kohno K, Yoshimoto G, Kikushige Y, Okeda A, Uike N, Niiro H, Takenaka K, Nagafuji K, Miyamoto T, Harada M, Takatsu K, Akashi K: Identification of the human eosinophil lineagecommitted progenitor: revision of phenotypic definition of the human common myeloid progenitor. J Exp Med 2009, 206:183-193

13. Ackerman SJ, Bochner BS: Mechanisms of eosinophilia in the pathogenesis of hypereosinophilic disorders. Immunol Allergy Clin N Am 2007, 27:357-375

14. Rådinger $\mathrm{M}$, Bossios $\mathrm{A}$, Sjöstrand $\mathrm{M}$, Lu $\mathrm{Y}$, Malmhäll $\mathrm{C}$, Dahlborn AK, Lee JJ, Lötvall J: Local proliferation and mobilization of CCR3(+) CD34(+) eosinophil-lineage-committed cells in the lung. Immunology 2011, 132:144-154

15. Percopo CM, Brenner TA, Ma M, Kraemer LS, Hakeem RMA, Lee JJ, Rosenberg HF: SiglecF + Gr1hi eosinophils are a distinct subpopulation within the lungs of allergen-challenged mice. J Leukoc Biol 2017, 101:321-328

16. Tan C, Wandu WS, St Leger A, Kielczewski J, Wawrousek EF, Chan C-C, Gery I: Unlike Th1/Th17 cells, Th2/Th9 cells selectively migrate to the limbus/conjunctiva and initiate an eosinophilic infiltration process. Exp Eye Res 2018, 166:116-119

17. Ueta M, Nakamura T, Tanaka S, Kojima K, Kinoshita S: Development of eosinophilic conjunctival inflammation at late-phase reaction in mast cell-deficient mice. J Allergy Clin Immunol 2007, 120:476-478

18. Baiula M, Bedini A, Carbonari G, Dattoli SD, Spampinato S: Therapeutic targeting of eosinophil adhesion and accumulation in allergic conjunctivitis. Front Pharmacol 2012, 3:203

19. Kari O, Haahtela T, Laine P, Turunen JP, Kari M, Sarna S, Laitinen T, Kovanen PT: Cellular characteristics of non-allergic eosinophilic conjunctivitis. Acta Ophthalmol 2010, 88:245-250
20. Radinger M, Lotvall J: Eosinophil progenitors in allergy and asthma do they matter? Pharmacol Ther 2009, 121:174-184

21. Gabanyi I, Muller PA, Feighery L, Oliveira TY, Costa-Pinto FA, Mucida D: Neuro-immune interactions drive tissue programming in intestinal macrophages. Cell 2016, 164:378-391

22. Benschop RJ, Rodriguez-Feuerhahn M, Schedlowski M: Catecholamine-induced leukocytosis: early observations, current research, and future directions. Brain Behav Immun 1996, 10:77-91

23. Yanagawa $Y$, Matsumoto $M$, Togashi $\mathrm{H}$ : Enhanced dendritic cell antigen uptake via alpha2 adrenoceptor-mediated PI3K activation following brief exposure to noradrenaline. J Immunol 2010, 185:5762-5768

24. Montoro J, Mullol J, Jáuregui I, Dávila I, Ferrer M, Bartra J, del Cuvillo A, Sastre J, Valero A: Stress and allergy. J Investig Allergol Clin Immunol 2009, 19 Suppl 1:40-47

25. Bianchimano P, Frias AI, Richeri A, Brauer MM: Effects of dexamethasone on estrogen- and pregnancy-induced plasticity in rat uterine sympathetic nerves. Cell Tissue Res 2007, 330:413-425

26. Bellinger DL, Lorton D: Autonomic regulation of cellular immune function. Auton Neurosci 2014, 182:15-41

27. Smith RE, Reyes NJ, Khandelwal P, Schlereth SL, Lee HS, Masli S, Saban DR: Secondary allergic $\mathrm{T}$ cell responses are regulated by dendritic cell-derived thrombospondin- 1 in the setting of allergic eye disease. J Leukoc Biol 2016, 100:371-380

28. Li D-Q, Zhang L, Pflugfelder SC, De Paiva CS, Zhang X, Zhao G, Zheng X, Su Z, Qu Y: Short ragweed pollen triggers allergic inflammation through Toll-like receptor 4-dependent thymic stromal lymphopoietin/OX40 ligand/OX40 signaling pathways. J Allergy Clin Immunol 2011, 128:1318-1325.e2

29. Lee HS, Schlereth S, Khandelwal P, Saban DR: Ocular allergy modulation to hi-dose antigen sensitization is a Treg-dependent process. PLoS One 2013, 8:e75769

30. Khandelwal P, Blanco-Mezquita T, Emami P, Lee HS, Reyes NJ, Mathew R, Huang R, Saban DR: Ocular mucosal CD11b+ and CD103+ mouse dendritic cells under normal conditions and in allergic immune responses. PLoS One 2013, 8:e64193

31. Nagasaki T, Zhao J: Uniform distribution of epithelial stem cells in the bulbar conjunctiva. Invest Ophthalmol Vis Sci 2005, 46:126-132

32. Bhowmick S, Singh A, Flavell RA, Clark RB, O'Rourke J, Cone RE: The sympathetic nervous system modulates CD4(+)FoxP3(+) regulatory $\mathrm{T}$ cells via a TGF-beta-dependent mechanism. J Leukoc Biol 2009, 86:1275-1283

33. Xue Y, He J, Xiao C, Guo Y, Fu T, Liu J, Lin C, Wu M, Yang Y, Dong D, Pan H, Xia C, Ren L, Li Z: The mouse autonomic nervous system modulates inflammation and epithelial renewal after corneal abrasion through the activation of distinct local macrophages. Mucosal Immunol 2018, 11:1496-1511

34. Gajendrareddy PK, Sen CK, Horan MP, Marucha PT: Hyperbaric oxygen therapy ameliorates stress-impaired dermal wound healing. Brain Behav Immun 2005, 19:217-222

35. Padgett DA, Marucha PT, Sheridan JF: Restraint stress slows cutaneous wound healing in mice. Brain Behav Immun 1998, 12:64-73

36. Tymen SD, Rojas IG, Zhou X, Fang ZJ, Zhao Y, Marucha PT: Restraint stress alters neutrophil and macrophage phenotypes during wound healing. Brain Behav Immun 2013, 28:207-217

37. Lu D, Lin C, Jiao X, Song Z, Wang L, Gu J, Li Z: Short-term high fructose intake reprograms the transcriptional clock rhythm of the murine extraorbital lacrimal gland. Invest Ophthalmol Vis Sci 2019, 60:2038-2048

38. Liu J, Xiao C, Wang H, Xue Y, Dong D, Lin C, Song F, Fu T, Wang Z, Chen J, Pan H, Li Y, Cai D, Li Z: Local group 2 innate lymphoid cells promote corneal regeneration after epithelial abrasion. Am J Pathol 2017, 187:1313-1326

39. Liu J, Xue Y, Dong D, Xiao C, Lin C, Wang H, Song F, Fu T, Wang Z, Chen J, Pan H, Li Y, Cai D, Li Z: CCR2(-) and CCR2(+) corneal macrophages exhibit distinct characteristics and balance inflammatory responses after epithelial abrasion. Mucosal Immunol 2017, 10:1145-1159 
40. Liu J, Wu M, He J, Xiao C, Xue Y, Fu T, Lin C, Dong D, Li Z: Antibiotic-induced dysbiosis of gut microbiota impairs corneal nerve regeneration by affecting CCR2-negative macrophage distribution. Am J Pathol 2018, 188:2786-2799

41. Mesnil C, Raulier S, Paulissen G, Xiao X, Birrell MA, Pirottin D, Janss T, Starkl P, Ramery E, Henket M, Schleich FN, Radermecker M, Thielemans K, Gillet L, Thiry M, Belvisi MG, Louis R, Desmet C, Marichal T, Bureau F: Lung-resident eosinophils represent a distinct regulatory eosinophil subset. J Clin Invest 2016, 126:3279-3295

42. Gautier EL, Shay T, Miller J, Greter M, Jakubzick C, Ivanov S, Helft J, Chow A, Elpek KG, Gordonov S, Mazloom AR, Ma'ayan A, Chua W-J, Hansen TH, Turley SJ, Merad M, Randolph GJ; Immunological Genome Consortium: Gene-expression profiles and transcriptional regulatory pathways that underlie the identity and diversity of mouse tissue macrophages. Nat Immunol 2012, 13:1118-1128

43. Griseri T, Arnold IC, Pearson C, Krausgruber T, Schiering C, Franchini F, Schulthess J, McKenzie BS, Crocker PR, Powrie F: Granulocyte macrophage colony-stimulating factor-activated eosinophils promote interleukin-23 driven chronic colitis. Immunity 2015, 43:187-199

44. Rose CE Jr, Lannigan JA, Kim P, Lee JJ, Fu SM, Sung SS: Murine lung eosinophil activation and chemokine production in allergic airway inflammation. Cell Mol Immunol 2010, 7:361-374

45. Voehringer D, van Rooijen N, Locksley RM: Eosinophils develop in distinct stages and are recruited to peripheral sites by alternatively activated macrophages. J Leukoc Biol 2007, 81:1434-1444

46. Iwasaki H, Mizuno S, Mayfield R, Shigematsu H, Arinobu Y, Seed B, Gurish MF, Takatsu K, Akashi K: Identification of eosinophil lineage-committed progenitors in the murine bone marrow. J Exp Med 2005, 201:1891-1897
47. Rothenberg ME, Hogan SP: The eosinophil. Annu Rev Immunol 2006, 24:147-174

48. Moriyama S, Brestoff JR, Flamar AL, Moeller JB, Klose CSN, Rankin LC, Yudanin NA, Monticelli LA, Putzel GG, Rodewald H-R, Artis D: beta2-adrenergic receptor-mediated negative regulation of group 2 innate lymphoid cell responses. Science 2018, 359: $1056-1061$

49. Irkec MT, Bozkurt B: Molecular immunology of allergic conjunctivitis. Curr Opin Allergy Clin Immunol 2012, 12:534-539

50. Scanzano A, Cosentino M: Adrenergic regulation of innate immunity: a review. Front Pharmacol 2015, 6:171

51. Kabata H, Artis D: Neuro-immune crosstalk and allergic inflammation. J Clin Invest 2019, 130:1475-1482

52. Mishra GP, Tamboli V, Jwala J, Mitra AK: Recent patents and emerging therapeutics in the treatment of allergic conjunctivitis. Recent Pat Inflamm Allergy Drug Discov 2011, 5:26-36

53. Miyazaki D, Nakamura T, Ohbayashi M, Kuo CH, Komatsu N, Yakura K, Tominaga T, Inoue Y, Higashi H, Murata M, Takeda S, Fukushima A, Liu FT, Rothenberg ME, Ono SJ: Ablation of type I hypersensitivity in experimental allergic conjunctivitis by eotaxin1/CCR3 blockade. Int Immunol 2009, 21:187-201

54. Elieh Ali Komi D, Rambasek T, Bielory L: Clinical implications of mast cell involvement in allergic conjunctivitis. Allergy 2018, 73: $528-539$

55. Xiao C, Wu M, Liu J, Gu J, Jiao X, Lu D, He J, Lin C, Xue Y, Fu T, Wang H, Wang G, Yang X, Li Z: Acute tobacco smoke exposure exacerbates the inflammatory response to corneal wounds in mice via the sympathetic nervous system. Commun Biol 2019, 2:33

56. Reyes NJ, Mayhew E, Chen PW, Niederkorn JY: gammadelta T cells are required for maximal expression of allergic conjunctivitis. Invest Ophthalmol Vis Sci 2011, 52:2211-2216 